\author{
U. Besterekov ${ }^{1}$, S.R. Yermekov ${ }^{1}$, I.A. Petropavlovskiy ${ }^{2}$ \\ ${ }^{I}$ M. Auezov South Kazakhstan State University, Shymkent, Kazakhstan; \\ ${ }^{2}$ D. Mendeleyev University of Chemical Technology of Russia, Moscow, Russia \\ (E-mail:sajat_78@mail.ru)
}

\title{
Values and change laws of atoms and ions radii
}

\begin{abstract}
In the chemical technology industry many products are produced by aqueous-salt systems. In such systems the charged particles of mineral substances used as raw materials are in the form of ions and play a decisive role in the formation of the target products. Today research results in the theoretical chemistry show that there is no high level scientifically substantiated data on the radii of atoms that are the material basis of such ion particles. The atomic and ion radius values of chemical elements give rise to several values for a single element in known literary data. These data are different from each other. Within the periodic table per each atom and each ion about 30 scaling values are determined by the calculation or physico-chemical methods. According to the results obtained, the values have been found that are close to the known data and preserve their own numerical values within the periodic system. At this point two different equations are used to calculate radii of the atoms and ions of the elements. Version 1 is for elements in the periodic table moving from period to another, while the other is for elements in the 1 st and 8 th groups in each period of the periodic table. All chemical elements in the periodic table allow calculating the radius values of atoms and ions.
\end{abstract}

Keywords: ion, atom, radius, periodic system, particle, charge, electron, physical and chemical properties.

\section{Introduction}

In many areas of chemical technology the processes occurring in aqueous-salt systems are used. In this case the mineral substances used as primary raw materials in the process are the elementary charge particles, ions, and play a decisive role in the formation of target products. Nowadays the research results [1-5] in scientific chemistry have shown that there is no high level scientifically substantiated data on the radii of such ion particles and their material basis. In general within the Periodic Table of Chemical Elements of D. Mendeleyev the data of radii determined by calculation and physico-chemical methods show about 30 scale values for each atom and each ion [6-11]. As examples we can include the research results on the radii of the ionic and atom particles [12] of Melvin-Hughes (MH), Goldschmidt (G), Poling (P), Ingold (In) and Boki (B) that are widely used in educational and scientific practice today (Table 1).

Ta b le 1

Radii of atoms and ions

\begin{tabular}{|c|c|c|c|c|c|c|c|c|c|c|}
\hline \multirow{2}{*}{ Elements } & \multicolumn{4}{|c|}{ Radius of atom, $r_{a} * 10, \mathrm{~nm}$} & \multirow{2}{*}{ Ion charge } & \multicolumn{5}{|c|}{ Radius of ion, $r_{i} * 10, \mathrm{~nm}$} \\
\cline { 2 - 7 } & $\mathrm{M} . \mathrm{H}$ & $\mathrm{G}$ & $\mathrm{P}$ & $\mathrm{B}$ & & $\mathrm{M} . \mathrm{H}$ & $\mathrm{G}$ & $\mathrm{P}$ & $\mathrm{In}$ & $\mathrm{B}$ \\
\hline $\mathrm{n}$ & 2 & 3 & 4 & 5 & 6 & 7 & 8 & 9 & 10 & 11 \\
\hline $\mathrm{Ag}$ & 1.445 & 1.44 & 1.53 & 1.44 & +1 & 1.014 & 1.13 & 1.26 & 1.26 & 1.13 \\
\hline $\mathrm{Al}$ & 1.432 & 1.43 & 1.26 & 1.43 & +3 & 0.55 & 0.57 & 0.50 & 0.72 & 0.57 \\
\hline $\mathrm{As}$ & 1.248 & 1.22 & 1.18 & 1.48 & +5 & - & 0.46 & - & 0.71 & $(0.47)$ \\
\hline $\mathrm{Au}$ & 1.442 & 1.44 & 1.50 & 1.44 & +1 & - & 1.37 & - & 1.37 & $(1.37)$ \\
\hline $\mathrm{B}$ & $(0.795)$ & 0.91 & 0.89 & 0.91 & +3 & $(0.20)$ & 0.23 & 0.20 & 0.35 & $(0.20)$ \\
\hline $\mathrm{Ba}$ & 2.174 & 2.17 & - & 2.21 & +2 & 1.395 & 1.34 & 1.35 & 1.53 & 1.38 \\
\hline $\mathrm{Be}$ & 1.113 & 1.11 & 1.07 & 1.13 & +2 & 0.314 & 0.35 & 0.31 & 0.44 & 0.34 \\
\hline $\mathrm{Bi}$ & 1.548 & 1.55 & 1.46 & 1.82 & +5 & - & 0.74 & - & 0.98 & $(0.74)$ \\
\hline $\mathrm{Br}$ & 1.1415 & 1.14 & 1.14 & - & +7 & - & - & - & 0.62 & $(0.39)$ \\
\hline $\mathrm{C}$ & 0.771 & 0.77 & 0.77 & 0.77 & +4 & 0.195 & 0.16 & 0.15 & 0.29 & 0.2 \\
\hline $\mathrm{Ca}$ & 1.974 & 1.37 & - & 1.97 & +2 & 1.051 & 0.99 & 0.99 & 0.99 & 1.04 \\
\hline $\mathrm{Cd}$ & 1.490 & 1.48 & 1.48 & 1.56 & +2 & 0.99 & 0.97 & - & 1.14 & 0.99 \\
\hline $\mathrm{Cl}$ & 0.994 & 0.99 & 0.99 & - & +7 & - & - & - & 0.49 & $(0.26)$ \\
\hline $\mathrm{Co}$ & 1.253 & 1.25 & 1.25 & 1.25 & +3 & 0.65 & 0.63 & - & - & 0.64 \\
\hline $\mathrm{Cr}$ & 1.249 & 1.25 & 1.25 & 1.27 & +6 & - & 0.52 & - & 0.81 & 0.35 \\
\hline $\mathrm{Cs}$ & 2.655 & 2.62 & - & 2.68 & +1 & 1.678 & 1.67 & 1.69 & 1.69 & 1.65 \\
\hline
\end{tabular}


Continuation of $\mathrm{Table} 1$

\begin{tabular}{|c|c|c|c|c|c|c|c|c|c|c|}
\hline 1 & 2 & 3 & 4 & 5 & 6 & 7 & 8 & 9 & 10 & 11 \\
\hline $\mathrm{Cu}$ & 1.278 & 1.27 & 1.35 & 1.28 & +2 & 0.47 & 0.72 & - & 0.96 & 0.80 \\
\hline $\mathrm{F}$ & 0.709 & 0.64 & 0.64 & - & +7 & - & - & - & 0.10 & - \\
\hline $\mathrm{Fe}$ & 1.241 & 1.26 & - & 1.26 & +3 & 0.67 & 0.64 & - & - & 0.07 \\
\hline $\mathrm{H}$ & 0.3707 & 0.36 & 0.30 & 0.46 & -1 & - & 1.53 & - & 2.08 & 1.36 \\
\hline $\mathrm{Hg}$ & 1.503 & 1.50 & 1.48 & 1.60 & +2 & 0.66 & 1.10 & - & 1.25 & 1.12 \\
\hline $\mathrm{I}$ & 1.333 & 2.20 & 1.28 & - & +7 & - & 0.50 & - & 0.77 & $(0.50)$ \\
\hline $\mathrm{K}$ & 2.272 & 2.36 & - & 2.36 & +1 & 1.341 & 1.33 & 1.33 & 1.33 & 1.33 \\
\hline $\mathrm{La}$ & 1.870 & 1.86 & - & 1.87 & +3 & 1.14 & 1.14 & 1.15 & 1.39 & 1.04 \\
\hline $\mathrm{Li}$ & 1.520 & 1.55 & 1.34 & 1.55 & +1 & 0.758 & 0.68 & 0.60 & 0.60 & 0.68 \\
\hline
\end{tabular}

\section{Results and discussions}

As can be seen form Table 1, there are large quantitative differences that can not be ignored for any element in their atomic and ionic radius values. The research findings show the results of recent research aimed at eliminating such shortcomings. The research has revealed that some of the latest scientific findings about the definite patterns of traction and drainage and the atomic structure, which arise between charged particles, have been used [13-17]. At this point two different equations are used to calculate the atoms and ions of the elements. For elements in version $1(1-3)$ elements according to their formula that move from period to period in the periodic table. They are lithium, sodium, potassium, rubidium, cesium, and francium.

$$
\frac{Z n e^{2}}{4 \pi \varepsilon_{0}\left(R_{\text {atom of previous element }}+X\right)^{2}}=\frac{K \cdot m \cdot v^{2}}{\left(R_{\text {atom of previous element }}+X\right)} .
$$

From the $1^{\text {st }}$ formula we find $X$.

$$
X=\frac{Z n e^{2}-K 4 \pi \varepsilon_{0} m v^{2} \cdot R_{\text {atom of previous element }}}{K 4 \pi \varepsilon_{0} m v^{2}} .
$$

Next, we find the atomic or ion radius of the element as follows:

$$
R_{\text {atom }}=R_{\text {atom of previous element }}+X \text {. }
$$

In version 2 (4-6) formulas are for the elements of 1 and 8 groups in each period in the Periodic Table. The laws are known that by an increase in the line number the atoms and ions radius of elements is decreased. Therefore, we deduce $X$ from the radius of the element and ion radius of the element, and we formulate the formula as follows.

$$
\frac{Z n e^{2}}{4 \pi \varepsilon_{0}\left(R_{\text {atom of previous element }}-X\right)^{2}}=\frac{K \cdot m \cdot v^{2}}{\left(R_{\text {atom of previous element }}-X\right)} .
$$

From the $4^{\text {th }}$ formula we find $\mathrm{X}$.

$$
X=\frac{K 4 \pi \varepsilon_{0} m v^{2} R_{\text {atom of previous element }}-Z n e^{2}}{K 4 \pi \varepsilon_{0} m v^{2}},
$$

here $\varepsilon_{0}$ - dielectric permeability of vacuum, $\mathrm{F} / \mathrm{m} ; e$ - electron charge, $\mathrm{C} ; m$ - electron mass, $\mathrm{kg} ; z-$ number of protons; $R$ - distance between the charged particles, $\AA ; v$ - velocity of rotating electrons in radius orbitals, $\mathrm{m} / \mathrm{sec}$.; $K-$ constant value determining by the arrangement of elements electrons in the cells.

Next, we find the atomic or ion radius of the element as follows:

$$
R_{\text {atom }}=R_{\text {atom of previous element }}-X \text {. }
$$

The new calculation results obtained for the elements described in Table 1 above are relative to the data given in Table 2, Figure 1.2. 
Table 2

Radii of atoms and ions

\begin{tabular}{|c|c|c|c|c|c|c|c|c|c|c|c|c|c|c|}
\hline \multirow[b]{2}{*}{$\begin{array}{l}\text { Ele- } \\
\text { ments }\end{array}$} & \multicolumn{6}{|c|}{ Atom radius, $r_{a} 10, \mathrm{~nm}$} & \multirow[b]{2}{*}{$\begin{array}{l}\text { Ion } \\
\text { charge }\end{array}$} & \multicolumn{7}{|c|}{ Ion radius $r_{i} 10, \mathrm{~nm}$} \\
\hline & M.H & G & $\mathrm{P}$ & B & $\begin{array}{l}\text { Average } \\
\text { literary }\end{array}$ & $\begin{array}{l}\text { Calcu- } \\
\text { lation }\end{array}$ & & M.H & G & $\mathrm{P}$ & In & B & $\begin{array}{l}\text { Aver- } \\
\text { age } \\
\text { literary }\end{array}$ & $\begin{array}{l}\text { Calcu- } \\
\text { lation }\end{array}$ \\
\hline $\mathrm{Al}$ & 432 & 1.43 & 1.26 & 1.43 & 388 & 1.383 & 3 & 0.55 & 0.57 & 0.5 & 0.72 & 0.57 & 0.582 & 0.575 \\
\hline As & 248 & 1.22 & 18 & 1.48 & & & & - & 46 & - & & .47 & 546 & \\
\hline $\mathrm{Au}$ & 442 & 1.44 & 1.5 & 1.44 & & & & - & 37 & - & & 1.37 & .37 & \\
\hline $\mathrm{B}$ & 795 & 0.91 & 0.89 & 0.9 & & & & 0.2 & 0.23 & 0.2 & & 0.2 & 36 & \\
\hline $\mathrm{Ba}$ & 174 & 2.17 & - & 2.2 & & & & 395 & 1.34 & 1.35 & 1. & 1.3 & & \\
\hline $\mathrm{Be}$ & 13 & 1.11 & 1.07 & 1.1 & & & & 0.314 & 0.35 & 0.31 & $0 .{ }^{2}$ & 0.3 & & 472 \\
\hline $\mathrm{Bi}$ & 548 & 1.55 & 1.46 & 1.8 & & & & - & 0.74 & - & 0.9 & 0.7 & & 681 \\
\hline $\mathrm{Br}$ & 41 & 1.14 & 1.14 & - & & & 7 & - & - & - & 0.6 & 0.39 & & \\
\hline $\mathrm{C}$ & 771 & 0.77 & 0.77 & 0.77 & & & 4 & .195 & 0.16 & 0.15 & 0. & 0.2 & & 0.213 \\
\hline $\mathrm{Ca}$ & 1.974 & 1.37 & - & 1.97 & 1.771 & 1.777 & 2 & 1.051 & 0.99 & 0.99 & 0.99 & 1.04 & 1.012 & 1.119 \\
\hline $\mathrm{Cd}$ & 1.49 & 1.48 & 1.48 & 1.56 & & & & 0.99 & 0.97 & - & 1.14 & 0.99 & & 1.989 \\
\hline $\mathrm{Cl}$ & 0.994 & 0.99 & 0.99 & - & & & & - & - & - & 0.49 & 0.26 & 0.375 & 0.372 \\
\hline Co & 253 & 1.25 & 1.25 & 1.25 & & & 3 & 0.65 & 0.63 & - & - & 0.64 & 0.64 & 0.333 \\
\hline $\mathrm{Cr}$ & 1.249 & 1.25 & 1.25 & 1.27 & & & 6 & - & 0.52 & - & 0.81 & 0.35 & 0.56 & 0.514 \\
\hline Cs & 655 & 2.62 & - & 2.68 & & 2.665 & 1 & 1.678 & 1.67 & 1.69 & 1.69 & 1.65 & 1.675 & 1.675 \\
\hline $\mathrm{Cu}$ & 1.278 & 1.27 & 1.35 & 1.28 & 1.294 & 1.405 & 2 & 0.47 & 0.72 & - & 0.96 & 0.8 & 0.737 & 0.985 \\
\hline$F$ & 0.709 & 0.64 & 0.64 & - & & & 7 & - & - & - & 0.1 & - & 0.1 & 0.099 \\
\hline $\mathrm{Fe}$ & 1.241 & 1.26 & - & 1.26 & & & 3 & 0.67 & 0.64 & - & - & 0.07 & 0.439 & 0.404 \\
\hline $\mathrm{Hg}$ & 1.503 & 1.5 & 1.48 & 1.6 & & 1.488 & 2 & 0.66 & 1.1 & - & 1.25 & 1.12 & 1.032 & 1.097 \\
\hline I & 1.333 & 2.2 & 1.28 & - & 1.203 & 1.283 & 7 & - & 0.5 & - & 0.77 & 0.5 & 0.59 & 0.426 \\
\hline
\end{tabular}

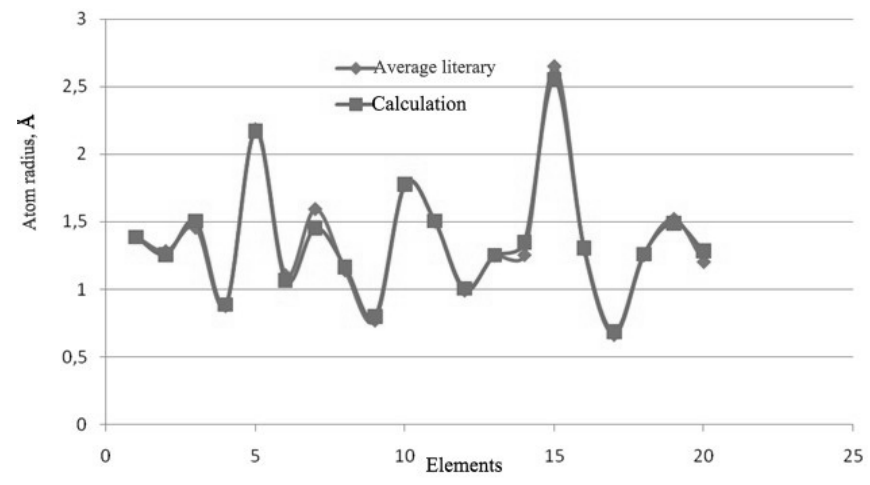

Figure 1. The laws of changes in average literary and calculation values of atomic radii

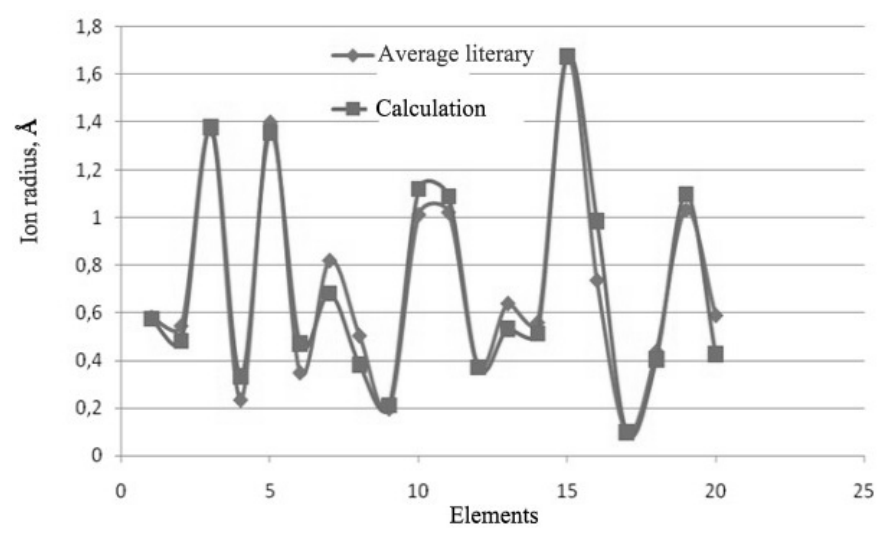

Figure 2. The laws of changes in average literary and calculation values of ion radii 


\title{
Conclusions
}

As shown in Table 2 and Figures 1, 2, the results of the study were close to the known data, and the values of the latter were changed within the periodic system, but their numerical values were obtained. In order to verify their superior sequence and authenticity, calculations were made using the atomic and ion radii of any element in the periodic system group before and after of that element, upper and under the certain periods, under certain elements. At the same time, in all four different calculations, the same values of the atom and ion radii of the element under consideration were obtained. This result can be a proof of the novelty of the findings, as well as the high scientific value and significance of it.

Thus, the results of the research can be considered as a new solution for calculating the high values of ion particles and their radicals' radii, which are their material basis in the field of chemistry. The methodology used in the work allow calculation of the radius values of atoms and ions all the chemical elements in the periodic system of D. Mendeleyev.

\section{References}

1 Киселев А.П. Основы общей химии: учебник / А.П. Киселев, А.А. Крашенинников. - СПб.: Балт. гос. техн. ун-т., 2012. $-340 \mathrm{c}$

2 Угай Я.А. Общая и неорганическая химия: учебник / Я.А. Угай. — М.: Высш. шк., 2000. - 529 с.

3 Чупахин А.П. Общая химия. Химическая связь и строение вещества: учеб. пособие / А.П. Чупахин. - Новосибирск: Изд-во Новосибир. гос. ун-та, 2003. - 166 с.

4 Тиноко И. Физическая химия. Принципы и применение в биологических науках / И. Тиноко, К. Зауэр, Дж. Вэнг, Дж. Паглиси. - М.: Техносфера, 2005. — 744 с.

5 Сережкин В.Н. Кристаллохимические радиусы и координационные числа атомов / В.Н. Сережкин, Д.В. Пушкин. Самара: Универс групп, 2005. - 64 с.

6 Потапов А.А. Способ измерения радиуса и энергии связи атомов и ионов / А.А. Потапов. - М.: Ин-т динамики систем и теории управления СО РАН, 2009. - $17 \mathrm{c}$.

7 Балданова Д.М. Плазменно-гидродинамическая концепция состояния ионов в растворах электролитов в оценке некоторых свойств / Д.М. Балданова, Б.Б. Танганов. - М.: Академия естествознания, 2012. — 99 с.

8 Патент № 2273058. Россия. Способ оценки радиусов атомов химических элементов в различном энергетическом состоянии / Родченко М.Б., Александров Б.Л. - Опубл. 2012.

9 Балданов М.М. Константа экранирования Слейтора-Зинера и радиусы одноатомных ионов / М.М. Балданов, Д.М. Балданова и др. // Известия вузов. Физика. - 2006. — Т. 49, № 3. - С. 59-67.

10 Балданов М.М. К проблеме радиусов гидратированных ионов / М.М. Балданов, Д.М. Балданова и др. // Доклады АН ВШ РФ. — 2006. — № 2(7). - С. 32-38.

11 Балданов М.М. Дисперсионное уравнение Власова и радиусы сольватированных ионов в метаноле / М.М. Балданов, Б.Б. Танганов // Журнал общей химии. - 1994. - Т. 64, № 1. - С. 32-34.

12 Краткий справочник физико-химических величин. - 8-е изд. / под ред. А. Равделя и А.М. Пономаревой. - Л.: Химия, 1983. - $232 \mathrm{c.}$

13 Сурнин С.П. Структура атома / С.П. Сурнин. - М.: Б.и., 2005. - 88 с.

14 Волков А.И. Строение атомов и периодический закон / А.И. Волков. — М.: Новое знание, 2006. — 196 с.

15 Детлав А.А. Курс физики / А.А. Детлав, Б.М. Яровский. - М.: Академия, 2007. - 720 с.

16 Калашников Н.П. Основы физики: учебник для вузов: в 2-х т. / Н.П. Калашников, М.А. Смондырев. - 3-е изд., стер. - М.: Дрофа, 2007.

17 Карапетьянц М.Х. Общая и неорганическая химия / М.Х. Карапетьянц, С.И. Дракин. — М.: Химия, 2015. — 592 с.

\section{У. Бестереков, С.Р. Ермеков, И.А. Петропавловский}

\section{Атомдар мен иондардың радиустары мәндері мен өзгеру заңдылықтары}

\begin{abstract}
Химиялық технология салаларында сулы-тұзды жүйелер арқылы көптеген өнімдер өндірілуде. Мұндай жүйелерде шикізаттар ретінде пайдаланылатын минералды заттардың зарядтық бөлшектері иондар түрінде болып, керекті өнімдерді қалыптастыруда шешуші рол атқарады. Ғылыми-ілімдік химия саласында қазіргі кезде қолжеткен нәтижелерді талдау нәтижесі көрсеткендей, осындай иондық бөлшектердің және олардың материалдық негізі болып табылатын атомдардың радиустары туралы шынайылылығы жоғары, толықтама ғылыми дәйектелген мәліметтер жоқ. Химиялық элементтердің атомы мен ионы радиустары мәндері белгілі әдеби мағлұматтарда бір элемент үшін бірнеше мән береді. Олар бір-бірінен өте алшақты мәндер. Химиялық элементтердің периодтық жүйесі кестесі шеңберінде радиустары есептік немесе сан алуан физика-химиялық жолдармен анықталған
\end{abstract}


мәліметтерде әр атом әр ион үшін 30 жуық шкалалық мәндер келтіріледі. Ізденіс нәтижелері бойынша белгілі мәліметтерге жақын және де соңғылардың периодтық жүйе шеңберінде өзгеру заңдылықтарын сақтайтын, бірақ өзіндік сандық нәтижелері бар мәндер алынды. Осы кезде элементтердің атомдары мен иондары радиустарын есептеуде екі түрлі теңдеулер қолданылады. 1-ші нұсқа элементтер периодтық жүйеде периодтан периодқа көшкендегі элементттер үшін, ал екіншісі периодтық жүйедегі әр периодтағы 1-ші және 8-ші топтағы элементттер үшін. Жұмыста қолданылған әдістеме Д. Менделеевтің периодтық жүйесіндегі барлық химиялық элементтердің атомдары және иондары радиустарының мәндерін есептеп анықтауға мүмкіндік береді.

Кілт сөздер: ион, атом, радиус, периодтық жүйе, бөлшектер, зарядтар, электрон, физика-химиялық қасиеті.

\title{
У. Бестереков, С.Р. Ермеков, И.А. Петропавловский
}

\section{Значения и закономерности изменения радиусов атомов и ионов}

\begin{abstract}
В отраслях химической промышленности многие продукты производятся с помощью водно-солевых систем. В таких системах заряженные частицы минеральных веществ, используемых в качестве сырья, находятся в форме ионов и играют решающую роль в формировании целевых продуктов. Результаты текущих исследований в области теоретической химии показали, что не существует высокоуровневых научно обоснованных данных о радиусах ионов и атомов. Атомные и ионные радиусы химических элементов имеют несколько значений для одного элемента по некоторым литературным данным. В данных о радиусах химических элементов периодической таблицы, определяемых физикохимическим и расчетным методом, каждый атом и ион имеют около 30 значений. По результатам исследования значения были близки к известным данным. Для вычисления радиусов атомов и ионов элементов используются два разных уравнения. Версия 1 предназначена для элементов в периодической таблице, перемещающихся из периода в период, а другая - для элементов 1-й и 8-й групп в каждом периоде периодической таблицы. Методология, используемая в работе, дает возможность рассчитать атомные и ионные радиусы всех химические элементов в периодической системе Д.И. Менделеева.
\end{abstract}

Ключевые слова: ион, атом, радиус, периодическая система, частицы, заряд, электрон, физикохимические свойства.

\section{References}

1 Kiselev, A.P., \& Krasheninnikov, A.A. (2012). Osnovy obshchei khimii [Basics of general chemistry]. Saint Petersburg: Baltic STU [in Russian].

2 Ugai, Ya.A. (2000). Obshchaia i neorhanicheskaia khimiia [General and inorganic chemistry]. Moscow: Vysshaia shkola [in Russian].

3 Chupakhin, A.P. (2003). Obshchaia khimiia. Khimicheskaia sviaz i stroenie veshchestva [General chemistry. Chemical bonding and structure of matter]. Novosibirsk: Novosibirsk SU publ. [in Russian].

4 Tinoko, I., Zauer, K., Veng, J., \& Pahlisi, J. (2005). Fizicheskaia khimiia. Printsipy i primenenie v biolohicheskikh naukakh [Physical chemistry. Principles and applications in biological sciences]. Moscow: Tekhnosfera [in Russian].

5 Serezhkin, V.N., \& Pushkin, D.V. (2005). Kristallokhimicheskie radiusy i koordinatsionnye chisla atomov [Crystal chemical radii and coordination numbers of atoms]. Samara: Univers grup [in Russian].

6 Potapov, A.A. (2009). Sposob izmereniia radiusa i enerhii sviazi atomov $i$ ionov [The method of measuring the radius and binding energy of atoms and ions]. Moscow: Institute of System Dynamics and Control Theory, Siberian Branch of the Russian Academy of Sciences [in Russian].

7 Baldanova, D.M., \& Tanganov, B.B. (2012). Plazmenno-hidrodinamicheskaia kontseptsiia sostoianiia ionov $v$ rastvorakh elektrolitov $v$ otsenke nekotorykh svoistv [Plasma-hydrodynamic concept of the state of ions in electrolyte solutions in the evaluation of certain properties]. Moscow: Akademiia estestvoznaniia [in Russian].

8 Rodchenko M.B., Aleksandrov B.L. (2012). Sposob otsenki radiusov atomov khimicheskikh elementov v razlichnom enerheticheskom sostoianii [The method of estimating the radii of atoms of chemical elements in a different energy state]. Patent No. 2273058 Russia. [in Russian].

9 Baldanov, M.M., \& Baldanova, D.M. et al. (2006). Konstanta ekranirovaniia Sleitora-Zenera i radiusy odnoatomnykh ionov [Slater-Zener shielding constant and monatomic ion radii]. Izvestiia vuzov: Fizika. — Russian Physics Journal, 49, 3, 59-67 [in Russian].

10 Baldanov, M.M., \& Baldanova, D.M. et al. (2006). K probleme radiusov hidratirovannykh ionov [To the problem of hydrated ion radii]. Doklady Akademii nauk Vysshei shkoly Rossiskoi Federatsii - Reports of Academy of Sciences of Higher School of Russian Federation, 2, 32-38 [in Russian].

11 Baldanov, M.M., \& Tangalov, B.B. (1994). Dispersionnoe uravnenie Vlasova i radiusy solvatirovannykh ionov $v$ metanole [Vlasov dispersion equation and the radii of solvated ions in methanol]. Zhurnal obshchei khimii - Russian Journal of General Chemistry, 64, 1, 32-34 [in Russian]. 
12 Ravdel, A., \& Ponomareva, A.M. (1983). Kratkii spravochnik fiziko-khimicheskikh velichin [Quick reference of physicochemical values]. (Edition 8). Leningrad: Khimiia [in Russian].

13 Surnin, S.P. (2005). Struktura atoma [Atom structure]. Moscow: B.i. [in Russian].

14 Volkov, A.I. (2006). Stroenie atomov i periodicheskii zakon [Atom structure and periodic law]. Moscow: Novoe znanie [in Russian].

15 Detlav, A.A., \& Yarovskii, B.M. (2007). Kurs fiziki [Course of Physics]. Moscow: Akademiia [in Russian].

16 Kalashnikov, N.P., \& Smondyrev, M.A. (2007). Osnovy fiziki [Fundamentals of physics]. (Vols. 1-2). Moscow: Drofa [in Russian].

17 Karapetyants, M.Kh., \& Drakin S.I. (2015). Obshshaia i neorhanicheskaia khimiia [General and inorganic chemistry]. Moscow: Khimiia [in Russian]. 